\title{
IMPACT OF GENDER, TYPE OF INSTITUTION AND LOCALITY ON THE ACADEMIC PERFORMANCE AIMONG B.ED., TRAINEES
}

KEY WORDS: Gender, Type of Institution, Locality, Teacher Trainees and Academic Performance.

\section{Hathiram Naik}

Post Graduate Teacher at TMRS, Wardannapet, Warangal Rural, Telangana State.

An attempt was made in the present investigation is Aim: Impact of gender, type of the institution and locality on the academic performance among B.Ed., trainees. Objective: To find out the differences in the Academic Performance among B.Ed., Trainees based on Gender, Type of Institution and Locality. Sample: Sample for the present study consists of 100 B.Ed., trainees in Warangal district of Telangana State. The subjects were in the age group of $21-25$ years selected and using stratified random sampling method. Conclusions: Females are better Academic Performance than males. There is no significant difference between Government and private B.Ed., trainees in Academic Performance. B.Ed., trainees of Private colleges are better Academic Performance than government colleges.

\section{INTRODUCTION}

Education is a light that shows the mankind the right direction to surge. If education fails to inculcate self-discipline and commitment to achieve in the minds of student, it is not their fault. We have to convert education into a sport and learning process has to generate interest in the students and motivate them to stay back in the institution than to run away firm it. Education should become a fun and thrill to them rather than burden and boredom. It is an integral part of their growth and helps than become good citizens.

Academic achievement has been a continuous to be one of the most important values held in high esteem in all cultures. It is an important developmental task, which every adolescent is expected to attain. Education widens the mind and trains the critical faculties of thought and judgment.

The dream of every student is to excel in the academic pursuits in school, college or university. It occupies a central role in the life of every student. It occupies pivotal place among the many tasks set before him. Parents also expect that their children should achieve academic success, so that it helps them to lead a better life and achieve their goals or ambitions. The performance has a pervasive effect on the student's personality.

\section{Review of Literature}

Haist et al., (2000) showed that men performed better than women in certain settings while women out performed men in other settings.

Kyong hee chee (2005) investigated gender differences in the academic ethic and academic achievement among college students. Results of analysis indicated that women are more likely to possess an academic ethic than men and that women also tend to have higher GPAs.

Joshi and Srivastava (2009) reported significant differences with regards to academic achievement of rural and urban adolescents. Urban adolescents scored higher in academic achievement as compared to rural adolescents. Significant gender differences were found in academic achievement. Girls were significantly higher on academic achievement as compared to boys.

Umadevi (2009) found that the relationship between emotional intelligence, achievement motivation and academic achievement of primary school student teachers. male and female, arts and science student's teachers do not differ in emotional intelligence and achievement motivation except academic achievement.

Aryana (2010) revealed that there was significant difference in academic achievement between boys and girls.
Kulkarni (2013) studied Academic Achievement among Tribal Students. A study was undertaken in three ashram schools in tribal areas. The results revealed that the students have potential to excel in academics but their academic achievement is low. The study concluded that the role of gender in academic performance is limited.

Azad Ahmad Andrabi (2015) studied the academic achievement among tribal and non-tribal adolescents of Kashmir. Results showed that tribal and non-tribal adolescents differ significantly on the measure of academic achievement at 0.001 level. Non-tribal adolescents were found to have a higher level of academic achievement than tribal students. The study also revealed that there is no significant difference between male and female adolescents on the measure of academic achievement.

Pargat Singh Garcha (2016) revealed that female teacher trainees have more academic achievement as compare to male teacher trainees. Urban teacher trainees have more academic achievement as compare to rural teacher trainees. Moreover significant difference exists between mean scores of academic achievement with respect to gender and residence.

Lucía Herrera, Mohamed Al-Lal and Laila Mohamed (2020) analyzed the relationship between academic achievement and different psychological constructs, such as self-concept, personality, and emotional intelligence. Secondly, to identify what dimensions of self concept, personality and emotional intelligence predict academic achievement. By gender, 192 were boys (47.2\%) and 215 girls (52.8\%), with an average age of 10.74 years old. By cultural group, 142 were of European origin (34.9\%) and 265 of Amazigh origin (65.1\%). The academic achievements were evaluated from the grades obtained in three school subjects: Natural Sciences, Spanish Language and Literature, and Mathematics.

\section{OBJECTIVE}

1. To find out the differences in the Academic Performance among B.Ed., Trainees based on Gender, Type of Institution and Locality.

\section{Hypotheses}

1. Male and female would not differ significantly in their Academic Performance among B.Ed.,Trainees.

2. Government and private colleges would not differ significantly in their Academic Performance among B.Ed.,Trainees.

3. Rural and urban areas students would not differ significantly in their Academic Performance among B.Ed.,Trainees.

\section{Methodology}

Sample

Sample for the present study consists of 100 B.Ed., trainees in 
Warangal district of Telangana State. The subjects were in the age group of 21-25 years selected and using stratified random sampling method.

\section{Procedure}

The management of MNR PG Teacher Education College has granted permission to collect data for the research from different colleges. Accordingly researcher has obtained the required information about the performance of B.Ed., teacher trainees from the Head of institution of various colleges. For the study researcher has selected performance of B.Ed., teacher trainees of two colleges. Researcher has Collected the data from university marks register and admission register.

\section{Variables Studied}

\section{Independent Variables}

1. Gender

2. Type of Institution

3. Locality

\section{Dependent Variable}

1.Academic Performance

Academic Performance: The Annual Marks obtained in B.Ed., trainees constituted the Academic Performance Scores.

\section{STATISTICAL ANALYSIS}

The obtained data were subjected to statistical analysis such as Means, SDs and 't' tests were used.

\section{RESULTS AND DISCUSSION}

Table-I: Means, SD's and ' $t$ ' values for the Academic Performance scores of Male and Female.

\begin{tabular}{|c|c|c|c|c|}
\hline Gender & N & Mean & SD & "t' Value \\
\hline Male & 50 & 339.81 & 36.21 & \multirow{2}{*}{$4.97 * *$} \\
\cline { 1 - 4 } Female & 50 & 378.60 & 41.52 & \\
\hline
\end{tabular}

**-Significant at 0.01 level

Hypothesis-1: Male and female would not differ significantly in their Academic Performance among B.Ed., Trainees.

Significant ' $t$ ' value of 4.97 reveals that there are significant differences between male and female with regard to their Academic Performance. Hence, hypothesis-1 Male and Female would not differ significantly in their Academic Performance is not accepted as unwarranted by results. It is proved that when comparison with mean scores, females (M: 378.60) are better Academic Performance than male (M: 339.81).

Table-II: Means, SD's and ' $t$ ' values for the Academic Performance scores of Government and Private college B.Ed.trainees.

\begin{tabular}{|c|c|c|c|c|}
\hline Type of Institution & N & Mean & SD & "t"Value \\
\hline Government & 50 & 337.85 & 34.00 & \multirow{2}{*}{$1.30 @$} \\
\hline Private & 50 & 362.80 & 40.66 & \\
\hline
\end{tabular}

@-Not Significant

Hypothesis-2: Government and private college students would not differ significantly in their Academic Performance among B.Ed., Trainees.

Insignificant ' $t$ ' value of 1.30 reveals that there are no significant differences between Government and Private institutions with regard to their Academic Performance. Hence, hypothesis-2 Government and Private institutions would not differ significantly in their Academic Performance is accepted as warranted by results. It is proved that when comparison with mean scores, Private B.Ed., trainees (M: 362.80) are better Academic Performance than government (M:337.85).
Table-III: Means, SD's and 't' values for the Academic Performance scores of Rural and Urban areas B.Ed. trainees.

\begin{tabular}{|c|c|c|c|c|}
\hline Locality & N & Mean & SD & "t" Value \\
\hline Rural & 50 & 351.00 & 40.412 & \multirow{2}{*}{$2.80 * *$} \\
\cline { 1 - 4 } Urban & 50 & 370.59 & 41.99 & \\
\hline
\end{tabular}

**-Significant at 0.01 level

Hypothesis-3: Rural and urban areas students would not differ significantly in their Academic Performance among B.Ed., Trainees.

Significant ' $t$ ' value of 2.80 reveals that there are significant differences between Rural and Urban areas B.Ed., trainees with regard to their Academic Performance. Hence, hypothesis-3 Rural and Urban would not differ significantly in their Academic Performance is not accepted as unwarranted by results. It is proved that when comparison with mean scores, urban areas B.Ed., trainees (M: 370.59) are better Academic Performance than rural areas B.Ed., trainees (M: 351.00).

\section{CONCLUSIONS}

1. Females are better Academic Performance than males.

2. There is no significant difference between Government and private B.Ed., trainees in Academic Performance.

3. B.Ed., trainees of Private colleges are better Academic Performance than government colleges.

\section{Education implications}

Universalization of elementary education is one of the prime concerns in India. In a country where most the girls are illiterate, better performance of women student teachers is a good indicator for quality education for girl's .From this study, a wide gap between theory and practical paper marks is observed. For this, while assigning marks in practical papers (methods of teaching) content and pedagogy knowledge of pupil teachers should be taken into account. For the sake of quality teacher education, infrastructure facilities, library and adequate staff members must be provide to different B.Ed colleges particularly to training colleges. The teacher educators of teacher education institutions should be oriented towards innovations in education for improvement of quality of teacher education in general and improvement of performance of student teachers in particular.

\section{REFERENCES}

1. Aryana (2010). Relationship between Self-esteem and Academic Achievement amongst Pre-University Students. Journal of Applied Sciences, 10(20), 2474-2477.

2. Azad Ahmad Andrabi (2015). A study of academic achievement among tribal and non-tribal adolescents of Kashmir. An international peer Reviewed and Referred, Scholarly Research Journal for Interdisciplinary studies, 3(21), Pp: 1278-1285.

3. Haist, S.A.,Wilson,J.F.,Elam, C.L., Blue, A.V., \& Fosson, S.E. (2000). The effect of gender and age on medical school performance: An important interaction. Advances in Health Sciences Education, 5(3), 197-205.

4. Joshi, S. \& Srivastava, R. (2009). Self-esteem and Academic Achievement of Adolescents. Journal of the Indian Academy of Applied Psychology, 35, 3339.

5. Kulkarni.V.V. (2013). Studied Academic Achievement among Tribal Students. Indian Journal of Applied Research, 3(3), Pp:366-368.

6. Kyong Hee Chee, Nathan W. PNo, and William Smith, (2005). Gender Differences in the Academic Ethic and Academic Achievement. College Student Journal, 604-618

7. Lucía Herrera, Mohamed Al-Lal and Laila Mohamed (2020). Academic Achievement, Self-Concept, Personality and Emotional Intelligence in Primary Education. Analysis by Gender and Cultural Group. Front. Psychol, 10,6-13.

8. Pargat Singh Garcha (2016). Influence of gender and residence on academic achievement of teacher trainees. Research gate, 1-7.

9. Umadevi, M.R. (2009). Relationship between Emotional Intelligence, Achievement Motivation and Academic Achievement. Edutracks, 8(12). 